\title{
Discrete Event Simulation Applying Lean methodologies: Case study. Wooden Sector
}

\section{Simulación de eventos discretos aplicando metodologías Lean: Estudio de caso. Sector de madera}

\author{
DOI: https://doi.org/10.17981/ijmsor.04.01.02
}

Research Article - Reception Date: Feb 8, 2019- Acceptance Date: Apr 22, 2019

\author{
Raiza Reyes-Mejia, Blass Troncoso-Mendoza and Alexander Troncoso-Palacio \\ Productivity and Innovation Department, Universidad de la Costa. Barranquilla (Colombia). \\ rreyes2@cuc.edu.co, btroncos@cuc.edu.co, atroncos1@cuc.edu.co
}

To reference this paper:

R. Reyes Mejía, B. Troncoso Mendoza, \& A. Troncoso Palacio "Discrete Event Simulation Applying Lean methodologies: Case study. Wooden Sector”, IJMSOR, vol. 4, no. 1, 2019. https://doi. org/10.17981/ijmsor.04.01.02

\begin{abstract}
In productive processes where parts are assembled, the assembly time is one of the most important problems that should be solved. Due to this, a case study was carried out in one company in the wooden sector, in which the Lean methodologies and the Discrete Events Simulation are integrated, to evaluate and improve the assembly processes of four-input wooden stowage. This study began by validating the process, then it was simulated in the Arena software, where great variability is observed in the assembly time of the four-input pallets, obtaining an average result of $25+/-2$ minutes. Due to this reason, the use of this methodology was proposed, applying the DMAIC cycle and carrying out controls in the process, it was possible to reduce it to $19+/-1$ minute per stowage unit assembled, which meant a $24 \%$ reduction in the time spent manufacturing. All of this positively influenced the final delivery time of the product, so, with this new time, the company could satisfy the demand of its customers, and will be able to place its product on the market in less time.

Keywords-- Assembly Stowage Wooden; Delivery Time Improvements; Lean Six Sigma; Operational Processes Improvements; Wooden Sector
\end{abstract}

Resumen-- En los procesos productivos donde las piezas se ensamblan, el tiempo de ensamble es uno de los problemas más importantes que deben resolverse. Debido a esto, se llevó a cabo un estudio de caso en una empresa del sector de la madera, en el que se integran las metodologías Lean y la Simulación de eventos discretos, para evaluar y mejorar los procesos de ensamblaje de estiba de madera de cuatro entradas. Este estudio comenzó validando el proceso, luego se simuló en el software Arena, donde se observa una gran variabilidad en el tiempo de ensamblaje de las paletas de cuatro entradas, obteniendo un resultado promedio de 25 +/- 2 minutos. Debido a esta razón, se propuso el uso de esta metodología, aplicando el ciclo DMAIC y realizando controles en el proceso, fue posible reducirlo a 19 +/- 1 minuto por unidad de estiba ensamblada, lo que significó una reducción del $24 \%$ en El tiempo dedicado a la fabricación. Todo esto influyó positivamente en el tiempo de entrega final del producto, por lo que, con este nuevo tiempo, la compañía podría satisfacer la demanda de sus clientes y podrá colocar su producto en el mercado en menos tiempo.

Palabras clave-- Estiba de ensamblaje de madera; mejoras en el tiempo de entrega; Lean Six Sigma; mejoras de procesos operativos; sector de madera 


\section{INTRODUCTION}

The stowage manufacturing industry has as main input the trees that are grown in the forests, from which wood is obtained, that is transformed into products of high added value, such as furniture and containers of products or packaging. According to the most recent data published by [1], in Colombia, the logging sector is very important because the wooden containers have an annual gross production coefficient of 3.7 plus an annual variation of 4.4 , which has reached a value in 2017 of around \$ 3.76 thousand million, equivalent to US $\$ 1,300$ million, as stated by [2], in the last five years, the wooden furniture industrial chain has maintained a constant participation in the total Gross Domestic Product of Colombia. The forest chain is composed of at least 6 links made up of organizations or companies dedicated to different tasks within the successive transformation processes. Companies or groups of companies must be able to measure their productivity, in terms of effectiveness and efficiency in relation to the results, resources used, quality, practices technologies or methods in use and their competitiveness. In [3], they explains how to set up your own bespoke, lasting productivity system to deliver outstanding results, Lean application alone often fails to increase productivity, therefore, it must migrate, evolving from "problematic sites" with uncertain futures to vibrant sites that attract reinvestment and growth. In the investigation by [4], [5], this type of analysis requires improvement plans focused on effective methodologies that provide systemic and scalable solutions. In the industrial round wood case, it can be used in several ways: As Parts for its transformation into sawn wood, which in turn is an input for the construction of various goods; as wood logs for veneers transformed into wooden boards for various purposes. Accessories for mining uses. As a support pole in the communications and construction in civil works. As wood agglomerates, that constitutes a basic input for the production of paper and cardboard, in addition to other industrial woods for multiple purposes.

\section{Literature REVIEW}

Being assertive in business decision-making is very important, so a very precise anal-ysis such as that offered by simulated models should be carried out. As we can see in the investigation of [6], they demonstrate through a simulated model the temporal causal adaptive network implementation was very important for decision making, using a model under acute stress. On the other hand, [7] proposed that Lean method-ology be used as an advanced tool to find profitability, increasing commercial and manufacturing operations, affirmed that, it also serves to solve complex problems in productive processes. This methodology it created by Dr. Mikel Harry, developed to control and decrease the variation in processes, in addition, it is also possible with this methodology to work with empirical data, according to [8] where a process reorgani-zation analysis was development, which were scientifically documented to improve productivity and quality. Also, this methodology application offers multiple perspec-tives on the success factors in companies. Around the world, Lean six sigma method-ology is also known by the acronym of its stages: Define, Measure, Analyze, Improve and Control. According to [9], by evaluating process statistics, activities can be im-proved, and it makes changes in workflows, as is mentioned in the investigation made by [10], where the Japanese developed give a statistical study, he affirmed that in all current university employees, data science skills need to be updated.

In different place around the world, Discrete Event Simulation has been developed to solve various problems in different areas of knowledge, next we will mention some cases: In research conducted by [11], is performed a simulation of an assortment system for a fabric and vinyl roll warehouse using Flexsim 6.0.2 software. where they got a $10 \%$ increase in efficiency. If we take into account what is proposed by [12], that once the problem defined, a simulation model could be built, knowing the input variables. In simulation of stochastic model as stated in [4], generated numbers in the simulation must follow a probability distribution theoretical. Also [13], showed that the entry analysis to the model would be: independence or randomness analysis, then homogeneity analysis, then goodness of fit analysis. In a simulation model, components must have identified. According to [14] and [15], process inputs and outputs and logical sequences should be analyzed, then validate the model to determine if the inferences drawn from the performance are correct and applicable to the system. Also [16] developed a mathematical model that recreates the behavior of the cocoa production chain and can be used to understand the chain dynamics as a whole, based on the information and material flows in the system. Studies carried by [17] in Quito city, manifest that there can be an improvement of communications in laboratories by using correlation analysis of pharmaceutical market strategies. Also according to [18], it conducted an analysis of the current situation of pharmaceutical companies in Ecuador, concluding that most pharmaceutical companies in the province of Guayas do not have a technological tool to automate their manufacturing processes. 
In the research conducted for [19], in Eindhoven, The Netherlands, identified the optimal supply decision, finding the probability that a manufacturer will deliver the product successfully. In [11], [20], it found through the simulation, a most technically feasible alternative from the economic point of view regarding the time of recovery of the investment. A microbiological laboratory in Mexico [21] a bacterial colony simulator was performed, which allowed generating samples that would control the growth parameters with better results, they performed a simulator of bacterial colonies, which allows generating samples that control growth parameters with better results are obtained, designed and pretest operational strategies for better care delivery. In Colombia, despite some isolated successes such as the one outlined by [22], historical approaches to forest management have failed to increase the country's forest heritage, and according with [23] and [24] Colombia is below the Latin American average in management practices, Because large companies have access to the best managers, while SMEs do not, and this is reflected in their performance.

Because in the literature reviewed in Science Direct, Scopus and Isi, no study of this type was found, this research will serve to provide an improvement in the wood sector, As the improvement obtained in the pharmaceutical sector by [25] where they used the simulation of discrete events for operational improvement in an analysis laboratory.

\section{Data Collection And Methodology}

According to [26], [27], [28], [29], [30], [31], the application of the Lean Six Sigma method-ology serves to help improve quality, reduce potential errors and improve business efficiency, in addition, for the characterization and study of processes, focusing on improvement of processes and reduction of the variability of them, where efficiency is guaranteed at the moment of manufacturing the products. The first step was to characterize each of the operations, develop and implement a series of formats where procedures will be documented in each production area for the process under study, thereby creating greater efficiency and productivity with respect to the activities that are carried out. They studied, in which the times of assembly of pallets were improved. Pursuant to [32] the competitiveness of small and medium companies can be improved by applying the Lean Six Sigma methodology.

Definition phase. The possible projects are identified that must be evaluated by management to avoid underutilization of resources. Once the project selected, the manager chooses to the most suitable team for development the project, it estab-lished the priority, its mission, its objectives and goals, which will be the economic estimates for the benefits that would be obtained with its execution

Measurement phase. Consists in the characterization of process through the identi-fication the key requirements the clients, the key characteristics of the product and the parameters (input variables) that affect the operation of the process and the characteristics or key variables. With this the measurement system is defined and the capacity of the process is measured.

Analysis phase. The team analyses the data of the current and historical results. Hypotheses on possible cause-effect relationships are developed and tested using the relevant statistical tools such as: Correlation study, ANOVA, Capacity Process, Regression analysis. In this way, the team confirms the variables of input or vitals that affect the response variables of the process.

Improvement phase: Current state of the process is very variable on average the assembly of a stowage is greater than $25 \mathrm{~min} / \mathrm{unit}$. This is why it is a challenge to improve this time so that the company increases its productivity and manages to stay in the market for much longer.

Control phase. Consists of designing and documenting the necessary controls to ensure that what is achieved through the Six Sigma project is maintained once the changes have been implemented. When the objectives have been achieved and the mission is completed. The sequence is shown in the following see Fig 1.

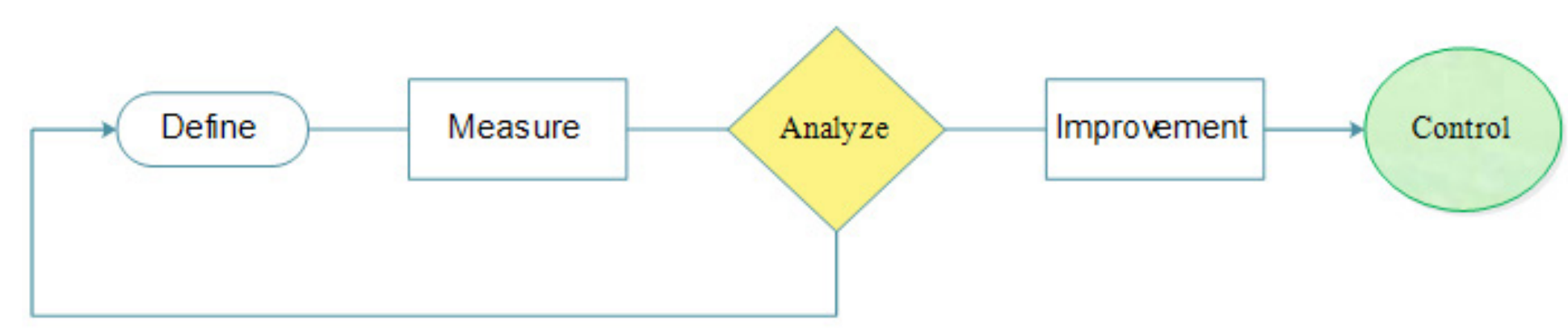

Fig. 1. Methodological approach: Diagnosis, Measure, Evaluation, Improvement and potential Control strategies. 


\section{Case study: Decrease in the Manufacturing TIMES OF FOUR-INPUT WOODEN STOWAGE}

Worldwide Around the world there is a considerable number of companies dedicated to the manufacture of wooden stowage, this segment is characterized by the presence of a large number of small businesses, most of them family, organized around a few large companies dedicated to The commercialization of wood stowage at national and international local level. In the company where this study applied, it found that during the previous year, the stowage of wood of four inputs manufactured, had a high variability in assembly times. In Fig. 2, the assembly process described by a flow chart, from the arrival of the wood, until the final product that is delivered to the warehouse obtained.

According to the methodology proposed in this document, it begins by defining the Project, which is the production of wood pallets, where the processing time is a key element to determine the capacity of the process, this will be measured in units man-ufactured per month. In this company, during the immediately preceding year the processing time has been highly variable, so the company think that it can increase the capacity of this process if reduce the processing times substantially. For the pro-ject the operational time is defined as the operational metric. Manufacture of pallets in the assembly process it is counted at the same time with the metric of units manu-factured per month for the reference of pallets of four entrances. Operational metric. The processing time in the assembly of the stowage of four inputs: The management decision of the company determined by its own, they considered as a defect when the duration of the assembly is greater than $22 \mathrm{~min}$. The measurement step was started by recognizing the process environment, to know through the SIPOC tool who are the suppliers, what are the inputs, what is done in the process, what are the outputs and who are the customers. The variables that affect the behavior of the assembly process of stowage wood and their sub processes are identified, for which a general pro-cess map was used for all the production lines. The company under study did not have a time record, therefore, it starts by creating a database in the Excel tool, to which the following analyses were made: goodness of fit tests, Randomness, Homo-geneity, and Regression statistics which is shown in the following in the Table 1 and Table 2.

TABle 1. Regression analysis.

\begin{tabular}{|l|l|}
\hline \multicolumn{2}{|c|}{ Regression statistics } \\
\hline Multiple correlation coefficient & 0.059195293 \\
\hline Coefficient determinatión $\mathrm{R}^{\wedge} 2$ & 0.003504083 \\
\hline $\mathrm{R}^{\wedge} 2$ adjusted & -0.006664243 \\
\hline Typical error & 1.168112847 \\
\hline Observations & 100 \\
\hline
\end{tabular}

Note: Regression analysis indicates that there is no correlation between the initial data and the improved process data.

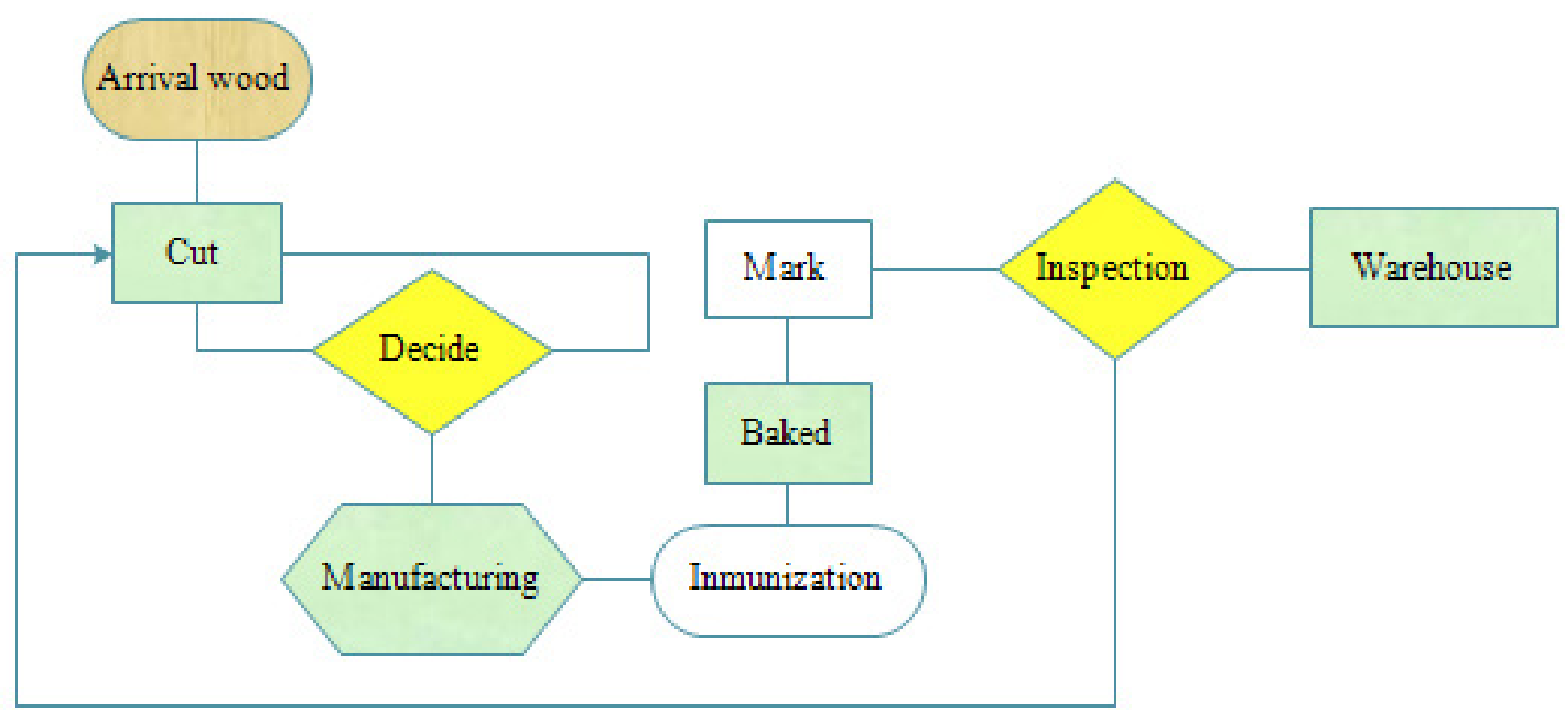

Fig. 2. Flow chart of wood stowage manufacturing.

TABle 2. ANOVA

\begin{tabular}{|l|l|l|l|l|l|l|}
\hline Origin of variations & Sum of square & Degrees of freedom & Squares average & $F$ & $P$ & $\begin{array}{c}\text { Value } \\
F\end{array}$ \\
\hline Between groups & 1969.71 & 1 & 1969.77 & 901.36 & $1.2 \mathrm{E}-75$ & 3.888 \\
\hline Within groups & 432.68 & 198 & 2.18 & & & \\
\hline Total & 2402.45 & 199 & & & & \\
\hline
\end{tabular}

Note: P-value negative 
Another very important input analysis is Goodnessof-fit test shows the process similarity with normal distribution, this statistic test decision criterion is based on the result of the p-values, if is greater than the level significance 0.05 , it considered random sequence; Else, the hypothesis is rejected. Fig. 3 shows the results obtained.

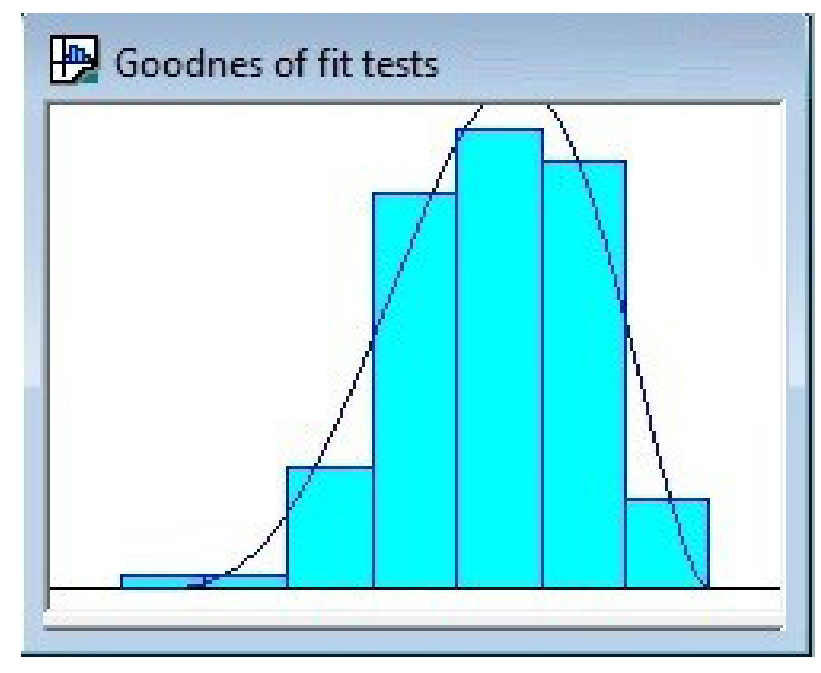

Fig. 3. Goodness-of-fit test.

Considering that if there are only common causes of variation in the process, the data will exhibit random behavior, the null hypotheses is that data have a random sequence [33]. This statistic test decision criterion is based on the result of the p-values, is greater than the level significance 0.05 then data are considered as following a random sequence. Otherwise, the hypothesis rejected. Then, an integration is made with the analysis obtained by applying Lean Six Sigma, and is designed in the Arena software, a model of the process with the DES methodology, which after validation will be used for the improvement proposals. Then, the integration of Lean Six Sigma with DES was carried out, because the statistical data of the input analysis obtained were used, with them the simulation of the process of assembling wooden pallets in the Arena software was built, which it is evidenced in the following Fig. 4.

After implementing the method, it controlled and maintained internally, recording daily for each production in the plant, the start and end times per activity, taking into account the reference of the product, since, depending on the same, the times vary by details in design. This format at the end of production is given to the assistant who verifies the standardized times by digitizing them in the management control format, where monthly the average of the data must coincide with the production standard for four-way pallets. When monthly we find differences with respect to the standard, we proceed to determine its cause through the fishbone method, we proceed to document the correction and preventive actions, which are annexed to management control and signed by the manager. The processes that intervened in the cause of the problem are committed to avoid reprocessing or delays in the development of the product. Two types of control, production control and management control were implemented.

\section{Conclusions}

In this investigation, it was possible to reduce up to $20 \%$ the time of assembling wooden pallets of four entrances, through the application of the Lean Six Sigma methodology as a statistical tool, which was ideal for the characterization and study of the processes. By integrating it with Simulation of Discrete Events, it was possible to focus on improving processes and reducing their variability; this ensures efficiency in the manufacturing process. With the results obtained it was possible to characterize each of the operations and develop and implement a series of ways where procedures are documented in each productive area. Regarding to the activities that were studied and in which the times were optimal with the modifications in the process, under the same conditions, the company could manufacture 59 complete units of the same reference. Assuming that the company could sell everything they manufacture, this company would obtain an income of $\$ 24,239,760$, and in addition, by applying the modifications, they would obtain a $\$ 4,865,990$ per month increment in their income.

It is recommended that small business production processes implement apply what is described in this article, so they can achieve more productivity and remain through time in the market.

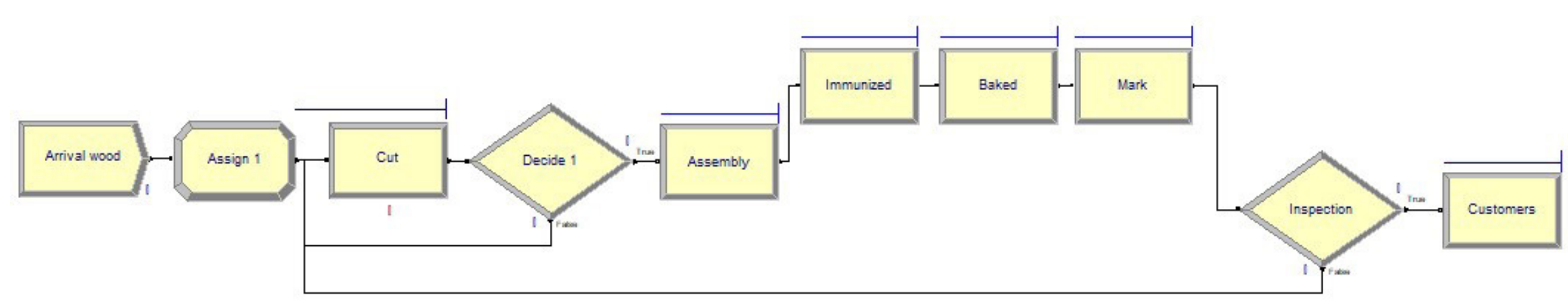

Fig. 4. Simulated model assembly process stowage. 


\section{ACKNOWLEDGEMENTS}

The authors wish to thank the "Paperthon 2018" and the participation of the Lean Decisions research group belonging to the Department of Industrial, Agro Industrial and Operations Engineering of the Universidad de la Costa.

\section{REFERENCES}

[1] DANE, "Annual Manufacturing Survey," Gobierno de Colombia, Bogotá, 2019

[2] I. M. Ospina, "Análisis de las PYMES del sector de muebles en Colombia a partir del ingreso de compañías y productos extranjeros," http://repositorio.uniagustiniana.edu.co/, Bogotá, 2018.

[3] P. Ostbo, R. Cattermole and M. Wetherill, Leading Beyond Lean, P. M. UK, Ed., London: Palgrave Macmillan, 2016.

[4] A. M. Sanchez and M. E. Rodriguez, "Propuesta de mejoramiento del proceso de atención a usuarios en un sistema con múltiples servicios y estaciones, usando técnicas y modelos de Simulación y su aplicación a la oficina de fianaciación y cartera de la Pontificia Universidad Javeriana Cali," Santiago de Cali, 2016

[5] A. León, "Propuesta de mejoramiento de los tiempos de respuesta del proceso de inscripción y admisión de la Pontificia Universidad Javeriana Cali aplicando la metodología DMAIC de seis SIGMA," vitela.javerianacali.edu.co, 2017.

[6] S. Mohammadi-Ziabari and j. Treur, "A Modeling Enviroment for Dynamic and Adaptative Network Models Implemented in MATLAB," Fourth International Congress on Information and Communication Technology. Advances in Intelligent Systems and Computing, vol. 1041, pp. 91-111, 2019.

[7] M. Joseph Gordon Jr, Six Sigma Quality for Business and Manufacture, Elsevier Science, 2002.

[8] T. Waurick, Prozessreorganisation mit Lean Six Sigma, Springer Gabler, 2014

[9] D. Donoho, "50 Years of Data Science," Journal of Computational and Graphical Statistics, vol. 26, no. 4, pp. 745-766, 2017.

[10] A. Takemura, "A new era of statistics and data science education in Japanese universities," Japanese Journal of Statistics and Data Science, vol. 1, no. 1, pp. 109-116, 2018.

[11] M. A. Alvarez, "https://ciateq.repositorioinstitucional.mx/ jspui/," 2017. [Online]. Available: https://ciateq.repositorioinstitucional.mx/jspui/handle/1020/66. [Accessed 2403 2020].

[12] K. Shawki, K. Kilani and M. Gomaa, "Analysis of earthmoving systems using discrete-event simulation," Alexandria Engineering Journal, vol. 54, no. 3, pp. 533-540, 2015.

[13] O. J. Herrera and L. A. Becerra, "Diseño General de las Etapas de Simulación de Procesos con Énfasis en el análisis de Entrada," in 12th Latin American and Caribbean Conference for Engineering and Technology, Guayaquil, 2014.

[14] C. Harrell, Ghosh and Bowden, Simulation Using Promodel, S. Edition, Ed., McGraw-Hill, 2017.

[15] A. Patiño, "Tendencias tecnológicas que influyen en el aumento de la productividad empresarial.," INGE CUC, vol. 11, no. 2, pp. 84-96, 2015.

[16] E. Pineda-Ballesteros and F. R. Tellez-Acuña, "Modelling and simulation of the Colombian cocoa production chain," INGE CUC, vol. 14, no. 1, pp. 141-150, 2018.

[17] E. D. Figueroa, "Análisis correlacional de las estrategias del mercado farmacéutico de productos antialérgicos para la mejora del mix comunicacional de los laboratorios farmacéuticos de la ciudad de Quito durante el periodo 20122014," Repositorio Digital Institucional BIBDIGITAL, Quito (Ecuador), 2016
[18] A. O. Yanza, O. Febles and V. Estrada, "Diagnosis of the level of automation of manufacturing processes for monitoring and control in the pharmaceutical industry of Guayaquil," International Journal of Innovation and Applied Studies, vol. 15 , no. 1, pp. 101-113, 2016.

[19] A. Akcay and T. Martagan, "Stochastic simulation under input uncertainty for contract-manufacturer selection in pharmaceutical industry," Washington, DC, USA, 2016.

[20] E. P. Sanchez F, D. Nuñez R, R. O. Cruz L, M. A. Torrez H and E. V. Herrera M, "Simulation and Counting of ColonyForming Units," Revista Electrónica RECIBE ISSN: 2007 5448, vol. 6, no. 1, pp. 97-111, 2017.

[21] N. Núñez-Pérez, M. Ortíz-Barrios, S. McClean, K. SalasNavarro, G. Jimenez-Delgado and A. Castillo-Zea, "Discrete-Event Simulation to Reduce Waiting Time in Accident and Emergency Departments: A Case Study in a District General Clinic," Lecture Notes in Computer Science, vol. 10586, pp. 352-363, 2017.

[22] H. A. Pérez-Olivera and B. I. Villalobos-Toro, "Competitive Analysis of the Wood and Forniture Industry of Barranquilla City," INGE CUC, vol. 6, no. 1, pp. 195-213, 2010.

[23] J. A. Gamez and C. Aguirre, "Management Practices and Their Impact on Performance: Evidence From the Furniture Sector in Colombia," in Handbook of Research on Entrepreneurial Leadership and Competitive Strategy in Family Business, IGI Global Disseminator of Knowledge, 2019, pp. 63-87.

[24] D. Landinez-Lamadrid, D. Ramirez-Ríos, D. N. Rodado, K. P. Negrete and J. C. Niño, "El valor de Shapley: sus algoritmos y aplicación en cadenas de suministro.," INGE CUC, vol. 13, no. 1, pp. 61-69, 2017.

[25] A. Troncoso-Palacio, D. Neira-Rodado, M. Á. Ortiz-Barrios, G. Jiménez-Delgado and H. Hernández-Palma, "Using Discrete-Event-Simulation for Improving Operational Efficiency in Laboratories: A Case Study in Pharmaceutical Industry," Lecture Notes Computer Science LNCS, vol. 10942, pp. 440-451, 2018.

[26] J. D. Rodriguez and F. Tobal, "Application of lean healthcare in hospital services: a review of the literature (2007 to 2017)," Production, vol. 28, 16072018.

[27] R. Reyes-Mejia and A. Troncoso-Palacio, "Reducción en los tiempos de operación en el proceso de armado de la fábrica reyes Mejía \& cia Ltda. de la ciudad de Barranquilla mediante la metodología de lean seis sigma," 2013.

[28] Boby John and Rajeshwar S. Kadadevaramath, "Improving the resolution time performance of an application support process using Six Sigma methodology," International Journal of Lean Six Sigma, 27022020

[29] E. Cudney, S. S. Jeemoonth Venuth, Tejaswi Materia and Jiju Antony, "Systematic review of Lean and Six Sigma approaches in higher education," pp. 231-244, 2018.

[30] Narottam, Mathiyazhagan and Vikas Sharma, "Defect Reduction in Manufacturing Industry Using Lean Six Sigma Approach," Lecture Notes in Mechanical Engineering, pp. 19-30, 2020.

[31] H. Sodhi, D. Singh and B. Singh, "A conceptual examination of Lean, Six Sigma and Lean Six Sigma models for managing waste in manufacturing SMEs," World Journal of Science, Technology and Sustainable Development, vol. 17 , no. 1 , pp. 20-32, 2020.

[32] P. Terán and A. Alvarado, "Mejoramiento de la competitividad en empresas PYMES del Ecuador aplicando Lean Six Sigma: estudio de un caso," Revista académica de la Universidad Santa María, Campus Guayaquil, vol. 1, no. 7, 2016.

[33] Minitab®18 Support, "support.minitab.com," [Online]. Available: https://support.minitab.com/en-us/minitab/18/ help-and-how-to/quality-and-process-improvement/qualitytools/supporting-topics/test-for-randomness/. 